\title{
THE MILITARY OPERATION EUNAVFOR MED IRINI - A DOWNSCALE OF THE EU'S INVOLVEMENT IN THE MIGRATION CRISIS
}

\author{
Marius PRICOPI \\ “Nicolae Bălcescu” Land Forces Academy, Sibiu, Romania \\ pricopimarius@yahoo.com
}

\begin{abstract}
Even though at a lower intensity from its 2015-2016 top, the migration crisis at the southern borders of the European Union is far from being over. But as it succeeds the military operation EUNAVFOR MED Sophia in the Mediterranean Sea, the new operation EUNAVFOR MED Irini has a very different mandate, focusing less on the migration events happening in the international waters and more on the United Nations arms embargo on Libya. Using as scientific tools the qualitative analysis of social documents and the exploratory case study, this paper argues that EUNAVFOR MED Irini, the newest military operation of the European Union, does not reflect the same level of the organisation's commitment to address the core causes that continue to generate the flow of illegal migrants.
\end{abstract}

KEYWORDS: EUNAVFOR MED Irini, European Union, migration, military operation

\section{Introduction}

When compared with the years 2015 2016, the flow of illegal migrants trying to reach Europe is currently lower, and it might seem that migration is no longer a threat for the security of the European continent. But according to the latest data (Braithwaite, 2020), in 2019 more than 100.000 migrants still tried to reach southern Europe through the Mediterranean Sea, of which over 1.200 dying in the attempt. Moreover, according to the European Asylum Support Office (Euronews, 2020), in 2019 the number of asylum seekers in the European Union (EU) rose for the first time since the peak of 2015 , and the trend is expected to continue.

It should therefore not be a surprise if a steady rise or spikes in the flow of migrants, generated by sudden changes of the highly volatile security climate in their countries of origin, might cause an overwhelming of the capacity of the European authorities to rescue lives in the international waters.

In the following, we argue that the ceasing of the military operation EUNAVFOR MED Sophia and its replacement with the more modest EUNAVFOR MED Irini represents a downscale of the European Union's involvement in the complex issues facing the Mediterranean area; among these issues, illegal migration remains the chief humanitarian concern looming at the EU's southern borders.

\section{Scientific Tool}

The scientific tool that has been used for researching and writing this paper combines elements of the qualitative analysis of social documents (Bowen, 2009) with the exploratory case study (Mills, Durepos \& Wiebe, 2010). 


\section{The Downsized Mandate of EUNAVFOR MED Irini}

In between June 2015-March 2020, the former EUNAVFOR MED Sophia has been the "flagship" of the European Union in its efforts to combat illegal migration in the Mediterranean Sea. The naval military operation has been a major success and, through its patrolling and search and rescue missions has managed to save no less than 45.000 lives at sea, arresting over 150 suspected smugglers and traffickers and removing more than 550 vessels from illegal organizations (European Commission, 2018).

But its successor, EUNAVFOR MED Irini (commenced on 31 March 2020), has a rather different purpose. According to its mandate, the core task of operation Irini is "the implementation of the UN arms embargo on Libya with aerial, satellite and maritime assets"; more specifically, the deployed forces can carry out "inspections of vessels bound to or from Libya where there are reasonable grounds to believe that such vessels are carrying arms or related material to or from Libya, directly or indirectly, in violation of the arms embargo on Libya" (Council of the European Union, 2020).

The only task of operation Irini that may be directly linked with the ongoing migration crisis is actually a secondary task that stipulates only a contribution to the disruption of the business model of the illegal networks that allow for human smuggling and trafficking.

Therefore, according to its mandate, EUNAVFOR MED Irini will not continue the active stance on illegal migration taken by EUNAVFOR MED Sophia and will not be actively and purposively involved in patrolling or the search and rescue of migrants that may find themselves in distress in the international waters.

\section{Who Will Continue to Carry the Burden?}

Without a doubt, Operation Sophia has had its share of criticism; according to some media reports, the search and rescue operations allegedly not only failed to limit the migration flow, as they actually encouraged asylum-seeking migrants to put additional risks on their lives. As an official of the Libyan coastguard stated at the time, "people, when they get rescued, call their friends to tell them that there are EU vessels only 20 miles from Libyan waters to save them" (EUOBSERVER, 2016).

Operation Sophia received considerable criticism even from inside the EU, more specifically in an official report adopted by the House of Lords, the Parliament's Upper House of the United Kingdom (still an EU member at the time of the report). The concerns stated regarded the arrests of mainly low-level smugglers, the change of tactics of the illegal migrants or the limited understanding of the modus operandi of the illegal traffic networks from mainland Libya. The overall recommendations of the report urged towards a tackle of not only the more visible consequences of the migration crisis, but of its core causes also, including the poor security climate in Libya. Nevertheless, even this critical report considered Sophia's search and rescue missions as "vital humanitarian obligations" (House of Lords, 2016).

So if EUNAVFOR MED Sophia ended and if EUNAVFOR MED Irini will not actively and purposively conduct patrolling or search and rescue missions in the international waters, who will? What will happen with the illegal migrants that might find themselves in distress deep at sea? Obviously, as long as the security situation in their countries of origin remains unstable, the migrants will continue to risk their lives in seeking a more safe and prosperous future, with or without the existence of a military presence in the Mediterranean Sea. 
It seems that, in lack of an EU military operation in the international waters, the burden falls on the southernborder member states and the European Border and Coast Guard Agency (FRONTEX), which is obliged to "provide technical and operational assistance to member states and non-EU countries" in support of these search and rescue missions "that may arise during border surveillance operations at sea” (FRONTEX, 2020).

Thus, once FRONTEX vessels reach the migrants in distress, officers provide medical assistance, food and water; afterwards, they hand over the migrants to national authorities (mainly Greece and Italy) for identification and registration. But there is a catch: the migrants in distress in international waters have to somehow first manage to alert the Maritime Rescue Coordination Centre or nearby vessels
- a task that might prove itself extremely difficult, in lack of appropriate transmission and communication means or prior basic training on how to use those means.

5. The Non-Governmental Actors Are Stepping Up Their Involvement The same absence of an intergovernmental EU military operation in the international waters has prompted various non-governmental organizations (NGOs) to take upon themselves the continuation of the necessary patrols and search and rescue missions of the illegal migrants.

Thus, according to the latest data, in June 2019 there were no less than 7 NGO ships operating in the Mediterranean Sea and involved in these types of operations in the international waters (Table no. 1).

Table no. 1

NGO Ships involved in search and rescue operations in the Mediterranean Sea

\begin{tabular}{|c|c|c|c|c|}
\hline No. & Vessel Name & Flag State & NGO & $\begin{array}{c}\text { NGO Country } \\
\text { of Registration }\end{array}$ \\
\hline 1 & Mo Chara & Sweden & Refugee Rescue & United Kingdom \\
\hline 2 & Moonbird & Switzerland & Sea-Watch & Germany \\
\hline 3 & Alan Kurdy & Germany & $\begin{array}{c}\text { Sea-Eye } \\
\text { PROEM-AID }\end{array}$ & Germany \\
\hline 4 & Josefa & Germany & RESQSHIP & Germany \\
\hline 5 & Mare Liberum & Germany & Mare Liberum & Germany \\
\hline 6 & Sea-Watch 3 & Netherlands & Sea-Watch & Germany \\
\hline 7 & Aita Mari & Spain & $\begin{array}{c}\text { Humanitarian Maritime } \\
\text { Rescue Association }\end{array}$ & Spain \\
\hline
\end{tabular}

(Source: European Union Agency for Fundamental Rights, 2019)

But even though the initiatives of the NGOs are commendable, their efforts surely lack the vast resources and planning and execution capabilities belonging to intergovernmental organizations; therefore their efforts, while they last, will only solve part of the problem. Moreover, according to media reports (European Union Agency for Fundamental Rights, 2020), these initiatives of the NGOs have been met with skepticism by some governmental authorities, that have even initiated various administrative and criminal proceedings against crew members and have seized or blocked in harbors different vessels that had flag issues or technical problems.

But NGOs are not the only non-state actors that get involved in the on-going 
migration crisis, as highly mediatised influent individuals play an active role also. Thus is the case of Banksy, an anonymous British street artist that captured the headlines of the 2020 summer not with his latest pieces of art, but with his decision to fund a ship involved in the search and rescue of illegal migrants. Bansksy's ship is a small (31 meters length) but fast motor-yacht, named after the French anarchist Louise Michel. Previously owned by the French custom authorities and now under German flag, the ship is colourfully painted in pink and white, "depicting a girl in a life vest holding a heart-shaped safety buoy” (Braithwaite, 2020) (obviously, a Banksy artwork).

The "Louise Michel" discreetly sailed from the Spanish Port of Burrinia on 18 August 2020, and in short time managed to save almost 200 migrants in two separate incidents. But as the ship could accommodate only 120 passengers on board and after health conditions worsened for many of the migrants, the crew issued via Twitter an urgent call for help; following the immediate need for assistance, the Italian coastguard evacuated 49 migrants with poor health ("dehydration, traumatic injuries, hypothermia and fuel burns" Braithwaite, 2020), while the others were transferred on board of another German ship, that was latter approved to dock in the Port of Palermo.

\section{Conclusions}

After more than five years, the migration crisis remains an extremely dividing issue. On the one side, activists and parts of the media are claiming that the European Union "turns its back on migrants in distress” (Sunderland, 2020) and portray the initiatives of the non-state actors as some sort of wake-up call for the European decision-makers. On the other side, in March 2019, EU's Migration Commissioner declared that the migration crisis is over, denouncing "misinformation, untruths and fake news" for the controversies surrounding the issue (Fox, 2019).

But beyond declarations and interpretations, the facts speak for themselves: in 2019 over 100.000 people tried to illegally cross the Mediterranean Sea and enter Europe; concurrently, the newest military operation of the European Union, EUNAVFOR MED Irini, does not actively and purposively conduct patrolling or search and rescue missions in the international waters, thus signaling a downscale of the EU's involvement in the migration crisis.

Therefore, in the absence of a specific EU military operation, the burden falls on FRONTEX, the EU southern border member states, non-governmental organisations and various activist individuals. But although obliged to intervene in an urgency call, ships belonging to FRONTEX and the border countries routinely patrol only in their territorial waters; also, the non-state actors who do take a stance on this issue lack a constant flow of resources and capabilities, while the planning and execution of their operations tend to be rather hasty and conducted on an ad-hoc basis.

And so, if from various uncontrollable reasons the flow of migrants will start to considerably increase, we might witness 2015-2016 all over again.

\section{REFERENCES}

Bowen, G. A. (2009). Document Analysis as a Qualitative Research Method. Qualitative Research Journal, Vol. 9, Issue 2, 27-40.

Braithwaite, M. (2020). Migrants moved off Banksy-funded rescue ship now seek port to dock, available at: https:/www.euronews.com/2020/08/29/street-artist-banky-s-boat-requestsugent-assistance, accessed on 07 September 2020. 
Council of the European Union. (2020). Council Decision (CFSP) 2020/472 of 31 March 2020 on a European Union military operation in the Mediterranean (EUNAVFOR MED IRINI), available at: https://eur-lex.europa.eu/legal-content/EN/TXT/PDF/ ?uri=CELEX:32020D0472\&qid=1599557771373\&from=EN, accessed on 09 September 2020.

EUOBSERVER. (2016). EU boosts migrant smuggling, says Libyan coastguard, available at: https://euobserver.com/tickers/133849, accessed on 10 September 2020.

Euronews. (2020). EU records first rise in asylum applications since height of 2015 migrant crisis: EASO, available at: https:/www.euronews.com/2020/06/26/eu-records-first-risein-asylum-applications-since-height-of-2015-migrant-crisis-easo, accessed on 07 September 2020.

European Commission. (2018). Central Mediterranean Route: Protecting migrants and managing irregular flows, available at: https:/lec.europa.eu/commission/sites/betapolitical/files/factsheet__ central_mediterranean_route.pdf, accessed on 09 September 2020.

European Union Agency for Fundamental Rights. (2019). NGO ships involved in search and rescue in the Mediterranean and criminal investigations, available at: https://fra.europa.eu/en/publication/2019/2019-update-ngo-ships-involved-search-and-rescuemediterranean-and-criminal, accessed on 12 September 2020.

European Union Agency for Fundamental Rights. (2020). NGO ships involved in search and rescue in the Mediterranean and legal proceedings against them, available at: https://fra.europa.eu/en/publication/2020/2020-update-ngos-sar-activities, accessed on 12 September 2020.

Fox, B. (2019). Migration crisis is "over", says EU chief, available at: https://www.euractiv.com/section/justice-home-affairs/news/migration-crisis-is-over-says-euchief/, accessed on 15 September 2020.

FRONTEX. (2020). Search and Rescue, available at: https://frontex.europa.eu/ operations/search-rescue/, accessed on 12 September 2020.

House of Lords. (2016). Operation Sophia, the EU's naval mission in the Mediterranean: an impossible challenge, available at: https://publications.parliament.uk/pa/ ld201516/ldselect/ldeucom/144/144.pdf, accessed on 10 September 2020.

Mills, A.J., Durepos, G., \& Wiebe, E. (2010). Encyclopedia of case study research Exploratory Case Study, available at: https://methods.sagepub.com/reference/encyc-of-casestudy-research/n139.xml, accessed on 07 September 2020.

Sunderland, J. (2020). EU turns its back on migrants in distress, available at: https://www.hrw.org/news/2020/02/18/eu-turns-its-back-migrants-distress, accessed on 14 September 2020. 